\title{
MAYOMBE: O ENTRECRUZAR DE VOZES NARRATIVAS E A CONSTRUÇÃO DA IDENTIDADE NACIONAL ANGOLANA
}

\section{Renildo Ribeiro *}

Resumo: Este texto propõe uma análise do livro Mayombe, do escritor angolano Pepetela, obra tem como foco central a construção da identidade nacional angolana e traduz o drama sócio-histórico de angola no período das guerras de libertação. Contada por vários narradores, a história do grupo de guerrilheiros do Mayombe aborda problemas como racismo, tribalismo e regionalismo de forma democrática e envolvente ao mesmo tempo em que busca expressar à angolanidade.

Palavras chave: literatura; história; identidade; utopia

Texto que rendeu a Pepetela o prêmio Nacional Angolano de Literatura de 1980, Mayombe já foi traduzido em várias línguas, mostrando aos vários países onde foi publicado a grandiosidade de seu escritor, que conseguiu captar a realidade sóciocultural angolana e inseri-la, em seu universo, literário de forma artística. Pepetela é o pseudônimo de Artur Pestana dos Santos. Esse pseudônimo, Pepetela, em quimbundo, significa "pestana", o que faz com que se perceba a marca/registro da defesa da identidade nacional que o escritor defende em suas obras. Mayombe, assim como as demais obras de Pepetela, tem como foco central a problemática da construção da identidade nacional angolana.

Para a análise a que nos propomos, partiremos dos quatro princípios evocados por Norman Friedman e citados por Ligia Chiapinni Moraes Leite ${ }^{1}$, e que, colocados como indagações, procuraremos responder ao longo do texto:

1- Quem conta a história ?

2- De que posição ou ângulo em relação à história o narrador conta?

Mestrando do Programa de Pós-Graduação em Letras e Linguística da Universidade Federal de Alagoas.

1 LEITE, Lígia Chiapinni Moraes. O foco narrativo. 6 ed..São Paulo: Ática (Princípios )1993, p.25. 
3- Que canais de informação o narrador usa para comunicar a história ao leitor?

4- Que distância ele coloca o leitor, da história?

Mayombe é uma obra que traduz, graças à grande maestria de seu autor, o drama social e histórico de Angola no período das guerras de libertação. Em Mayombe, o foco narrativo está centrado nas ações de um grupo de guerrilheiros que luta contra as tropas do exército português. ${ }^{2}$ Apesar de ter o conflito entre colonizador e colonizado como foco central e imediato da obra, Pepetela a constrói com tão grande maestria que o referido conflito acaba sendo utilizado como uma espécie de pretexto para abordar problemas internos de ordem mais geral, como: racismo, tribalismo e regionalismo. O conflito colonizador versus colonizado, apesar de ser um fato historicamente vivenciado pela sociedade angolana e pelos próprios escritores, foi utilizado em Mayombe apenas como um fator situacional, sem deixar de lado sua importância histórica, impulsionando os conflitos de ordem interna, acima mencionados.

Episódios historicamente ocorridos como os citados por Agostinho Neto, que diz: "as autoridades fascistas mataram e mataram recorrendo a métodos tão horrendos como agrupar pessoas e passarlhes o bulldozer por cima, ", são lembrados através de personagens que assim se referem ao fato acima mencionado: "Era miúdo na altura de 1961. Mas lembro-me ainda das cenas de crianças atiradas contra as árvores, de homens enterrados até o pescoço, cabeça de fora, e o trator passando, cortando as cabeças com a lâmina feita para abrir terra, para

2 É importante salientar que existiam tropas portuguesas que traziam angolanos como guerrilheiros, eram as chamadas "tropas especiais".

3 AGOSTINHO NETO, Antonio. Tudo pelo povo, pela independência, tudo pelo socialismo. Luanda: Edições do Ministério da Defesa; Gráfica Popular UEE, 1979, p.6-8 Apud BACCEGA, Maria Aparecida. Mayombe: ficção e história (uma leitura em movimento). Tese de Doutorado. O autor: mimeo. Departamento de Letras Clássicas e Vernáculas da Faculdade de Filosofia, Letras e Ciências Humanas da Universidade de São Paulo, 1985, p. 74. 
dar riqueza aos homens (Mayombe, p. 32). ${ }^{4}$ Observa-se que Pepetela utilizou-se do que Antônio Cândido ${ }^{5}$ chamou de redução estrutural, isto é, utilizou-se dos fatos constituintes do mundo que o cercava e recriou um mundo ficcional, que traz em si a essência, o cerne do mundo do qual foi derivado.

Já foi dito acima, e é importante destacar, que boa parte dos poetas, escritores e ficcionistas angolanos fazem ou fizeram parte do MPLA (Movimento Popular de Libertação de Angola). O autor de Mayombe não poderia fugir à regra. Após integrar, por vários anos, 0 quadro de militante do MPLA e assumir cargos no governo, o autor de Mayombe decide abandoná-los. Pepetela, porém, como vários outros escritores angolanos, tenta incorporar a realidade social e transformar a palavra num instrumento vivo de combate ao colonialismo, ao regionalismo e ao tribalismo.

Como dissemos anteriormente, o foco central da obra de Pepetela está voltado para a construção da identidade nacional angolana. No entanto, esta não é uma característica particular do escritor em estudo. Escritores e poetas angolanos como Manuel Rui, Henrique Abranches, José Luandino Vieira, Arnaldo Santos, Costa Andrade, dentre outros, também estão voltados para a construção da identidade nacional. Através dessas literaturas, percebemos 0 compromisso de seus escritores com a transformação de seus países. Tais escritores acreditavam que a literatura era um meio de conscientização que teria maior eficácia sobre a nação em desenvolvimento.

Segundo Pepetela, a literatura

É um fator que ajuda a aumentar a unidade nacional, por ser veículo de conhecimento de situações, modos de vida e de pensar, dentro do País. Talvez nem todos os escritores se tenham percebido disso, e talvez por isso não façam esforço por continuar a escrever. Penso que a

4 PEPETELA. Mayombe. São Paulo: Ática, 1982. A partir de agora, essa edição do romance será referenciada no texto através da inicial $M$, seguida do número da página.

5 CANDIDO, Antônio. $O$ discurso e a cidade. São Paulo: Duas Cidades, 1993. 
literatura, tomada como parte da cultura nacional, que cria, ou assimila a criação, duma consciência própria de um povo e que se distingue assim dos outros.[...] Não pode haver a criação de um país verdadeiramente independente sem uma literatura nacional próxima, que mostre aquilo que o povo sempre soube: isto é, que tem uma identidade própria. ${ }^{6}$

Percebemos, no entanto, a importância da literatura na construção de um projeto utópico. A literatura, neste caso, é o elemento que critica o presente na intenção de cancelar tudo que veio antes e recomeçar uma nova história em um novo mundo. Eis o motivo que faz com que projetos utópicos e nacionalistas, como é o caso do projeto defendido pelos escritores e intelectuais angolanos e expresso através de suas obras, sejam de realizações não imediatas.

Apesar de Angola ser um país com alto grau de analfabetismo, o que poderia tornar incoerente a utilização da literatura com o objetivo de conscientizar a população, os escritores, que também eram intelectuais, acreditavam que as literaturas engajadas eram um meio de se chegar até os demais intelectuais e estes, por sua vez, entrariam em contato com os formadores de opinião que terminavam por transmitir às massas os ideais defendidos pelos escritores em seus projetos artísticos. Como diz Carvalho Filho", "o imaginário veiculado pelas literaturas tem a possibilidade de criar o clima intelectual, colaborando, desse modo, para a formação de uma sensibilidade coletiva." Pois, segundo Carvalho, os escritores angolanos eram membros de estratos letrados e detentores de alto grau de ocidentalização, podendo idealizar uma nação de maneira diferente das pessoas comuns, todavia a sensibilidade de alguns escritores capta este ideário mesmo que inconscientemente.

A forma de idealizar a conquista da independência entre os estratos letrados, ocidentalizados e os cidadãos comuns é um dos

6 Inquérito aos escritores. Responde Pepetela. Lavra \& Oficina: UEA, n5, fev.1979, p.4 e 12.

7 CARVALHO FILHO, Silvio de Almeida. "Imaginário sobre nação na literatura angolana (1975-1985). In: Atas do I Seminário das Literaturas Africanas de Língua Portuguesa. Faculdade de Letras/UFRJ,1996. p.16. 
grandes problemas enfrentados pelos guerrilheiros e pode ser observada no fragmento abaixo, retirado do discurso do personagem Milagre, em que se percebem também fortes tensões tribais:

E agora Lutamos fala aos trabalhadores. Talvez explique que os quis avisar antes, mas que foi descoberto. E deixam-no falar! O Comandante não liga, ele não estava em Angola em 1961, ou, se estava, não sofreu nada. Estava em Luanda, devia ser estudante, que sabe ele disso? E o Comissário. Ele pensa que é com boas palavras que se convence o povo de Cabinda, este povo de traidores (M, p. 32-33).

O que torna Pepetela singular no universo literário angolano é o fato de ele ser hoje quase que, exclusivamente, o nome da literatura angolana identificado com o romance como forma de expressão. ${ }^{8} \mathrm{O}$ romance, enquanto gênero literário, sempre exerceu uma impressionante atração sobre os escritores angolanos, visto que tais escritores se encontram imersos num movimento cultural marcado pela tradição oral, o que faz com que as obras dos mesmos dividam-se entre contos e romances, romances e poemas, poemas e contos. $\mathrm{O}$ próprio Pepetela, no tempo de estudante em Lisboa, chegou a escrever alguns contos nas famosas antologias da "Casa dos Estudantes do Império." No entanto, apesar de se enveredar no teatro por duas vezes, é como autor de narrativas longas (romances) que Pepetela se firma no projeto literário angolano. $\mathrm{O}$ fato de Pepetela ter experiências com teatro faz com que Mayombe nos traga alguns traços típicos da linguagem teatral.

Quando se pergunta quem é o narrador em Mayombe, dizemos que os fatos são narrados ora em terceira pessoa, ora em primeira, sendo que o narrador em terceira pessoa é uma espécie de fio condutor da narrativa que apresenta uma visão onisciente dos fatos. O narrador

8 CHAVES, Rita. "Pepetela: romance e utopia na história de Angola" In: Via atlântica. Departamento de Letras Clássicas e Vernáculas. Faculdade de Filosofia, Letras e Ciências humanas. Universidade de São Paulo. $n^{\circ} 2$ julho de 1999. São Paulo: Departamento: 1999, p.218. 
em terceira pessoa é o que Maria Gabriela Costa ${ }^{9}$, em seu artigo "O Concerto das vozes em Mayombe, de Pepetela" chamou de maestro/narrador, que distribui ordenadamente as palavras à diferentes personagens e que vão se alternando numa sequência narrativa-discurso-narrativa. Esse narrador nos apresenta os fatos ao mesmo tempo em que nos emite informações do que se passa na mente dos personagens e observa o comportamento dos mesmos." Sem Medo identificou-se a uma nuvem cinzenta, com fimbrias brancas, que corria em revolução constante, e parecia poder escaparse, poder passar ao lado da massa de nuvens que se adensava sobre o Mayombe (M, p 113).

Já os narradores em primeira pessoa são personagens que têm como baliza de suas atitudes e de seus comportamentos os acontecimentos que vivenciam e que vivenciaram no passado. Esses personagens tomam a palavra e fazem-nos seus depoimentos, contamnos sua história, seus motivos de adesão ao movimento e dirigem-se ao leitor através de interrogações, muitas vezes fazendo duras críticas ao MPLA:

O MPLA expulsa os melhores, só porque eles não se deixam dominar pelos Kikongos, que o invadiam. Pobre MPLA! Só na Primeira Região, ele ainda é o mesmo, o movimento de vanguarda. E nós os da Primeira Região, forçados a fazer a guerra aqui, numa região alheia, onde não falam a nossa língua, onde o povo é contrarevolucionário, e nós que fazemos aqui? (M, p. 33).

$O$ fato de o narrador se dirigir ao leitor através de interrogações é bastante significativo: primeiro, porque coloca o leitor dentro da problemática desenvolvida no decorrer do romance, concedendo-lhe um tom confidencial; e, segundo, porque obriga 0 leitor a tomar decisões e, com isso, "participar" da construção textual.

9 COSTA, Maria Gabriela "O Concerto das Vozes em Mayombe, de Pepetela". In:Littera; revista de Estudos lingüísticos e Literários. São Luís: Departamento de letras da Universidade Federal do Maranhão, 2002, p.217. 
IDENTIDADE NACIONAL ANGOLANA

A mudança de foco narrativo, em Mayombe faz com que o texto seja construído por micronarrativas que se integram a uma macronarrativa, ou seja, dentro da história que narra o conflito entre portugueses e angolanos, realizado na floresta tropical de Cabinda (Mayombe) e em Dolísie, povoado civil mais próximo. Pepetela introduz várias narrativas em primeira pessoa, sempre iniciadas pela expressão: “Eu, o narrador, sou ..." Para Costa, o fato de os narradores, em primeira pessoa, iniciarem seus depoimentos com essa expressão faz com que assumam "a marca registrada da sua singularidade, como forma de assegurar o lugar social que lhes pertence $^{10}$." Rita Chaves, ${ }^{11}$ por sua vez, afirma que em Mayombe articula-se a essas marcas da democratização da voz o mencionado peso dos diálogos, que, segundo Pepetela, ${ }^{12}$ foi concebido inicialmente para ser um roteiro cinematográfico.

A presença dos vários narradores em Mayombe vem não só confirmar a influência da linguagem cinematográfica no texto, mas também destacar a opção do autor em não dar voz a um único sujeito, o que seria incoerente para um país pluri-étnico e pluricultural que se encontra ao final de séculos de colonização. O compartilhar discursivo existente em Mayombe é uma característica utópica que, juntamente com a idéia de construção de uma identidade nacional, traz em si a idéia de comunhão e partilha muito presente na obra em estudo.

No processo narrativo, ao dar voz aos personagens, Pepetela simula, como que pedagogicamente, a democratização desta voz, o que o faz ir de encontro ao paradigma tradicional, fazendo com que o homem angolano passe de objeto falado a sujeito falante. ${ }^{13}$ No entanto, Maria Aparecida Baccega faz uma interessante observação a respeito da concessão das vozes narrativas em Mayombe, pois "Ocorre que para se dar palavra a cada militante, há que respeitá-lo na sua individualidade, e para dar voz a cada indivíduo e respeitá-lo na sua

10 Idem, p. 218.

11 Idem, p. 221

12 Afirmação feita a Rita Chaves numa entrevista concedida em 1987.

13 GARCIA, Flávio. "Pepetela: o escritor Guerrilheiro de Mayombe". Atas do I Seminário das Literaturas Africanas de Língua Portuguesa. Faculdade de Letras da UERJ, 1996,.p.57-60. 
individualidade, há de se conhecer efetivamente as condições sociais que o geraram. ${ }^{14}$

Pepetela não só conhecia as condições sociais que geraram os conflitos e que levaram cada indivíduo à guerrilha, como também viveu esta realidade. Segundo Mariana Pinho Cândido, ${ }^{15}$ Pepetela é típico representante da elite crioula já que,

Como vários crioulos mostrou-se favorável à independência e ao estado socialista, chegando a integrar as tropas do MPLA. Entre 1958 e 1962, vivendo em Lisboa, participava das reuniões da Casa dos estudantes do Império, onde teve seus primeiros contatos com pessoal ligado ao MPLA, conscientizando-se sobre a realidade angolana e publicando pequenos artigos antes de 1961.[...] No final da década de 60 marca sua ida à guerrilha, primeiro à Cabinda, depois à Frente Leste, onde escreveu seu primeiro romance publicado As aventuras de Ngunga.

A utilização dos vários narradores ainda reafirma o caráter oral do novo texto que passará a ter marcas da angolanidade.

Se para Pires Laranjeira, ${ }^{16}$ africanidade é:

Uma doutrina que inclui componentes geográficos, etnológicos, históricos, míticos, linguiísticos, religiosos, etc., que constituem e caracterizam o discurso do africano negro na sua herança assumida e no seu

14 BACCEGA, Maria Aparecida. Mayombe: ficção e história (uma leitura em movimento) Tese de Doutorado. O autor: mimeo. Departamento de Letras Clássicas e Vernáculas da Faculdade de Filosofia, Letras e Ciências Humanas da Universidade de São Paulo, 1985, p. 187.

15 CANDIDO, Mariana Pinho. Pepetela: um olhar sobre a construção da cultura nacional. Monografia de Bacharelado. $\mathrm{O}$ autor: mimeo. Instituto de Filosofia e Ciências Sociais - Departamento de História.Universidade Federal do Rio de Janeiro Rio de Janeiro, 1997, p.37.

16 LARANJEIRA, Pires. "As Literaturas africanas de Língua Portuguesa Identidade e Autonomia" In: Escripta, Belo Horizonte, v. 3, n. 6, $1^{\circ}$ sem.2000, p. 238. 
visionário profético, forjadores de uma nova identidade social e cultural,

Podemos dizer, parafraseando o autor, que a angolanidade, elemento alvejado pelos escritores angolanos, é também uma doutrina que inclui componentes geográficos, etnológicos, históricos, míticos, linguiísticos, religiosos, etc., que constituem e caracterizam o discurso do angolano crioulo na sua herança assumida e no seu visionário profético, forjadores de uma nova identidade social e cultural.

Como vimos, Mayombe é uma obra em que os fatos narrados se desenvolvem em dois espaços geograficamente distintos: a floresta tropical de Cabinda da qual, não aleatoriamente, provém o título da obra; e o espaço urbano que está representado através de Dolísie, povoado civil mais próximo. No entanto, a maior parte das ações e conflitos narrados desenvolve-se no espaço geográfico do Mayombe.

O espaço urbano é citado na obra muito poucas vezes, posto que o foco narrativo está centrado no homem angolano e em suas ações enquanto guerrilheiro. As referências feitas a Cabinda são mais para fazer críticas ao movimento, que tem como representante 0 dirigente André, totalmente avesso ao ideal que se espera de um dirigente/militante e herói.

A floresta do Mayombe é um ambiente paradoxal que, ao mesmo tempo em que une os iguais, conflita os diferentes, assim como protege, cria obstáculos:

A mata criou cordas nos pés dos homens, criou cobras à frente dos homens, a mata gerou montanhas intransponíveis, feras, aguaceiros, rios caudalosos, lama, escuridão, medo. A mata abriu valas camufladas de folhas sob os pés dos homens, barulhos imensos no silêncio da noite, derrubou árvores sobre os homens. E os homens avançaram. e os homens tornaram-se verdes, e dos seus braços folhas brotaram, e flores, e a mata curvou-se em abóbada, e a mata estendeu-lhes a sombra protetora, e os frutos (M, p. 71).

A floresta do Mayombe também pode ser configurada como um local utópico. Essa configuração deve-se não só por ser descrita como algo paradoxal, visto que o conceito de utopia em si já é um 
paradoxo, mas por ser um ambiente de partilha e comunhão. Um outro fator que ajuda na configuração da floresta como um meio utópico é o fato de esta encontrar-se protegida das influências externas. Existe uma espécie de aura que se forma em torno da floresta para proteger os que ali sobrevivem. A floresta é o ambiente de contato entre tropas do exército português e tropas angolanas. Dessa forma, Mayombe reúne os iguais e os posiciona em grupos distintos: colonizador versus colonizado. Entretanto, há um outro tipo de conflito que os angolanos terão de superar para que o colonizador possa ser realmente derrotado. As diferenças etno-grupais é que deveriam ser superadas antes do confronto com o colonizador.

A unidade nacional estava construída sobre a luta de independência, contudo isso não bastaria, já que essa sociedade multilingüística e multicultural necessitava de novas metas. É o que percebemos na fala do Comissário Político, no momento em que estão decidindo a pena que será aplicada a um dos guerrilheiro, o Ingratidão do Tuga: "somos nós, com a nossa fraqueza, o nosso tribalismo, que impedimos a aplicação da disciplina. Assim nunca se mudará nada." (M, p.64). O tribalismo era uma espécie de competitividade que ocorria entre membros de tribos diferentes. Esse fenômeno surgia no setor tradicional da economia que era formado por nativos ligados à agricultura. O próprio Comandante Sem Medo tem consciência do obstáculo imposto pelo tribalismo: ${ }^{17}$ "Para eles, o que se passa na Europa não é tribalismo. Está bem, já não há tribos, o nome está incorreto. Mas há um fenômeno muito semelhante. Às vezes eu fico desesperado, aqui. Será que conseguiremos vencer este mal?" (M, p. 168).

A Floresta do Mayombe é o deus intransponível. É um ambiente que comporta mistérios. É um lugar exterior que pela sua imagem permite expressar o não-lugar, o inexpressivo do interior ${ }^{18}$ :

17 Voltaremos a abordar o problema do tribalismo quando estivermos nos referindo às personagens.

18 VÁZQUES, Adolfo Sánches,. Entre a realidade e a utopia. Ensaios sobre política, moral e socialismo. Trad.Gilsom B. Soares. Rio de Janeiro: Civilização Brasileira, 2001. 

IDENTIDADE NACIONAL ANGOLANA
À noite, na mata, o melhor guarda era a impenetrabilidade do Mayombe. $\mathrm{O}$ inimigo não sabia 0 lugar para onde tinham retirado, por isso os obuses de morteiro caíam a uns cinco quilômetros para a direita. Os morteiros, aliás, não eram utilizados como arma ofensiva, mas apenas para levantar a moral dos soldados tugas, cercados numa mata desconhecida e temível, que escondiam monstros aterrorizadores. $\mathrm{O}$ barulho aterrorizava-os, dava-lhes consciência de seu poderio, protegia-os do seu próprio medo (M, p. 55-56).

O Mayombe é o deus, não só que protege, mas o deus que tem o poder de transformar, de criar e até mesmo de alimentar seus filhos. Somente a floresta tem o poder de unir o diverso e firmar a identidade do homem que sobrevive dela e nela:

O Mayombe tinha aceitado os golpes dos machados que nele abriram uma clareira. [...] as casas tinham sido levantadas nessa clareira e as árvores, alegremente, formaram uma abóbada de ramos e folhas para as encobrir. [...] um montículo foi lateralmente escavado e tornou-se forno para pão. Os paus mortos das paredes criaram raízes e agarraram-se à terra e as cabanas tornaram-se fortalezas. E os homens vestidos de verde tornaram-se verdes como as folhas e castanhos como os troncos colossais. [...]A comida faltava, e a mata criou as "comunas", frutos secos, grandes amêndoas, cujo caroço, era partido à faca e se comia natural ou assado (M, p.70).

Percebemos, na obra em análise, que a natureza é algo que ganha vida na narrativa e possibilita o diálogo, o confronto e a metamorfose dos elementos nela integrados. A floresta é o lugar da intocada profundidade africana, lá não há diferenças civilizacionais, nem intelectuais, "os homens vestidos de verde tornaram-se verdes". No Mayombe todos são iguais, como fala Sem Medo a Teoria: "Hoje tu já não tens cor, pelo menos no nosso grupo de guerrilheiro, estás aceite, completamente aceite." (M, p. 44).

Os guerrilheiros estão ligados pelo mar de sofrimentos e opressão que faz com que haja uma grande escala de solidariedade, como o reflete estas palavras de Muatiânvua, o personagem/guerrilheiro que tem nome de rei : 
O mar une, o mar estreita, o mar liga. Nós também temos o nosso mar interior, que não é o Kuanza, nem o Loje, nem o Kunene. O nosso mar, feito de gotas diamante, suores e lágrimas esmagados, o nosso mar é o brilho da arma bem oleada que faísca no meio da faísca no meio da verdura do Mayombe, lançando fulgurações de diamante ao sol da Lunda (M, p.133).

Apesar das divergências conceituais, os guerrilheiros estão unidos pela busca da liberdade, pelo construção de uma nação angolana que tenha por característica o compartilhar de valores, onde o diverso esteja harmoniosamente integrado ao uno, havendo dessa forma o respeito à diversidade socio-cultural:"Como é dramático ter sempre de escolher, preferir um caminho a outro, o sim ou o não! Por que no mundo não há lugar para o talvez? Estou no Mayombe, renunciando a Manuela, com o fim de arranjar no universo maniqueísta o lugar para o talvez (M, p.12).

Um dos fatores que aproxima o conceito de nação e utopia diz respeito à construção e à realização de ambas. Utopia e Nação têm em comum o fato de serem categorias de realização não imediatas. Como bem colocou Costa, os guerrilheiros, "num universo quase proustiano, eles vão em busca de um tempo passado que lhes permita assentar os medos/angústias de um tempo presente e lhes alimente os desejos/esperanças de um tempo futuro ${ }^{19}$."

Alguns guerrilheiros como Sem Medo tem consciência de que o projeto pelo qual estão lutando não é de realização imediata e que não chegarão a usufruir dos benefícios advindos do mesmo:

Quando acabar a guerra. Quando fizeres parte de um Partido vitorioso e glorioso que conquistará o poder e que considerará pagãos todos os que dele não fizerem parte. Quando estiveres sentado no poder, pertencendo ao grupo restrito que dominará o Partido e o estado, depois da primeira desilusão de constatar na prática que o socialismo não é obra de um só dia, ou da vontade de mil homens (M, p.121).

19 Idem, p.217. 


\section{E ainda:}

Ora! Vamos tomar o poder e que vamos dizer ao povo? Vamos construir o socialismo. E afinal essa construção levará 30 ou 50 anos. Ao fim de cinco anos, o povo começará a dizer: mas esse tal socialismo não resolveu este problema ou aquele. E será verdade, pois é impossível resolver tais problemas, num país atrasado, em cinco anos (M, p 120).

Sendo Mayombe uma obra construída através do entrecruzamento dos diversos discursos provenientes de vários narradores, pode-se dizer que essas narrativas, ou melhor, essas vozes narradoras se entrecruzam na construção de um projeto utópico que deveria ser concretizado na conquista da independência nacional e na construção da identidade nacional angolana. Essa identidade, segundo a ideologia dos poetas e escritores angolanos, seria construída através da fusão e do reconhecimento da fusão dessas várias identidades etnolinguíísticas, culturais e regionais. Tal pensamento defendido pelos escritores angolanos é adotado por E. Renan e Benedict Anderson, para quem o ideal de nação tem a ver com uma comunidade, cuja coesão está fundada no compartilhar de valores.

A "composição polifônica" ${ }^{20}$ em Mayombe serve, de certa forma, para questionar a possibilidade de criação de uma identidade nacional que pudesse se sobrepor a identidades étnicas de forma a não suprimi-las ou descartá-las. Em outras palavras, Pepetela questiona como construir uma identidade nacional angolana sem favorecer certas etnias. E esse é um dos motivos pelo qual dá voz aos personagens e deixa que os mesmos façam seus questionamentos, sem que, em momento algum, o narrador ou os narradores tomem um partido qualquer.

Na tentativa de fazer com que os angolanos refletissem sobre tais questões, Mayombe foi construído a partir de personagens típicas. Para melhor entendermos a noção de personagem típico, recorremos a Ovsiannikov, citado por Baccega:

20 Esta expressão foi usada por Maria Gabriela Costa no artigo aqui referido. 


\begin{abstract}
O típico não é apenas uma abstração árida de um traço característico, nem a "mediocridade" naturalista, nem o "ideal" de Schiller, mas sim uma unidade dialética das características substanciais, na qual se reflete, em toda a riqueza, a vida com suas contradições sociais, morais, filosóficas e ideológicas mais importantes da época. O típico congrega organicamente os fenômenos naturais e concretos, universais e historicamente transitórios, de significado social universal e individual ${ }^{21}$.
\end{abstract}

As várias personagens de Mayombe, cada uma com suas particularidades, vão construindo, ao longo da narrativa, como que uma colicha de retalhos na qual estão inseridas as condições sociais de Angola no ano de 1971.

A realidade descrita na obra é a do mundo colonial em transformação. Entretanto essa realidade, esse mundo, só é apresentado através das várias vozes narrativas que se encontram várias vezes convergindo e divergindo em determinados pontos. Os personagens têm consciência de que lutam por um projeto, um sonho utópico que, como toda utopia, jamais terá realização imediata. Usando as palavras de Baccega, ${ }^{22}$ dizemos que a verdadeira libertação nacional se dá ao mesmo tempo em que o indivíduo constrói irreversivelmente sua liberdade.

Nós sabemos que a libertação individual, após séculos de colonização, não é algo simples. Muito menos um processo de mão única onde apenas um dos lados é dominante e o outro é dominado, ou um dos lados influencia e o outro é influenciado. Como diz Fanon, ${ }^{23}$
A luta de libertação não restitui à cultura nacional seu valor e seus contornos antigos. Essa luta que visa uma redistribuição fundamenta! das relações entre os homens não pode deixar intacta as formas nem os conteúdos culturais desse povo. Após a luta não há apenas o

21 OVSIANNIKOV, M. F. Fundamentos da estética marxista-leninista. Moscou: Progresso, 1982, p.31. Apud BACCEGA, op. cit. p.57-58.

22 Idem p. 55.

23 FANON, Franz. Os condenados da terra. Rio de Janeiro: Civilização Brasileira, 1998. p.205. Apud BACCEGA, op. cit, p.70-71 
desaparecimento do colonialismo; há também o desaparecimento do colonizado.

Tendo na literatura um elemento de formação ideológica, considerado eficiente e significativo na mobilização das massas, Pepetela se preocupa em transmitir através de suas obras a imagem do bom guerrilheiro. Esse guerrilheiro, assim como Ogun, o Prometeu africano, tem o poder de firmar homens em oposição aos deuses.

Sem Medo é o comandante do grupo de guerrilheiros que está atuando na base militar localizada na floresta tropical do Mayombe, em Cabinda. Suas principais características são o niilismo, o individualismo e o quase pessimismo, o que pode ser encarado como uma característica positiva do personagem. Sem Medo sabe que a liberdade não é conquistada apenas pela vitória na guerrilha. Devido a sua experiência em guerras, era o único do grupo capaz de entender o drama pessoal de cada um, ao mesmo tempo que tinha a facilidade de registrar em sua mente cada ação e atitude de seus guerrilheiros para, logo que necessário, convocá-lo para determinada função:

Lutamos está nervoso, inquieto, notou Sem Medo. O Teoria está a sofrer, mas finge que não. O Ekuikui ... esse é sempre o mesmo. Ingratidão está desconfiado do Lutamos. Mundo Novo deve está a pensar na Europa e nos seus marxistas-lenninistas. Os pensamentos do Comandante iam mais longe. Eram fotografias que tirava aos elementos do grupo e que classificavam num ficheiro mental, sem mais se preocupar. Quando necessário servia-se dessas informações para ter uma imagem fiel de cada guerrilheiro e saber que tarefa dar a cada um. (M, p. 21).

O personagem Sem Medo, além de possuir as características acima mencionadas, não tem o intuito de mobilizar os companheiros através de teorias político-sociológicas. Sua forma de mobilização é através de ações, o que faz com que os guerrilheiros o imitem ou sintam a necessidade de imitá-lo e enfrentar honrosamente os vários deuses que os oprimem e retardam a marcha em direção à liberdade. Essa postura é demonstrada claramente na narração do personagem Lutamos, que, para opor-se ao tribalismo e ao regionalismo dos quais é vítima, sente-se na obrigação de ser como Sem Medo, mesmo que 
tal ação o leve à morte, mas ele necessita mostrar aos demais, na condição de representante de seu povo, sua grandeza. Temos então a construção do herói da modernidade que, ao contrário de Prometeu e de outros deuses gregos, encontra sua purificação e seus objetivos não só através dos sofrimentos, mas sobretudo através da morte:

Amanhã, no ataque, quantos naturais de Cabinda haverá? Um, eu mesmo. Um, no meio de cinquienta. Como convencer os guerrilheiros de outras regiões que o povo de Cabinda não é só feito de traidores? Como os convencer que eu próprio não sou traidor? [...] Estivemos sempre juntos, ele [Sem Medo] sabe que não trairei. Mas quantos são os que pensam como ele? Vai embora, foi dito que se vai embora para o Leste. Quem me defenderá dos outros, quem terá a coragem de se opor ao tribalismo? [...] Terei de ser eu a impor-me, sendo mais corajoso que ninguém. E Nazambi sabe como tenho medo! Mas que será feito do meu povo se o único Cabinda se portar mal? [...] Depois de amanhã, no combate, serei como o Sem Medo. O meu povo exige (M, p. 257-258).

No que diz respeito à evocação do passado para solucionar eventuais problemas ou se chegar a determinadas conclusões, por ser um veterano de guerra e profundo conhecedor da realidade vivida, Sem Medo dá preferência a "viver o presente", e talvez essa fosse a forma mais verdadeira e viável de conquistar a liberdade individual e concretizar o projeto em desenvolvimento:

Os homens gostam de se flagelar com o passado e nunca se sentem contentes sem o fazer. É a incapacidade de pôr uma pedra sobre um fato e avançar para o futuro. Há outros, no entanto, que não sabem gozar a vida, que só vêem o futuro. Incapacidade de sofrer ou gozar uma situação. Se sofrem, consolam-se, pensando que o amanhã será melhor. Se são felizes, temperam essa felicidade pela idéia de que ela acabará breve. Eu vivo o presente. Eu vivo o presente; quando faço amor não penso nas vezes em que não encontrei prazer, ou que será necessário lavar-me a seguir (M, p.117). 

IDENTIDADE NACIONAL ANGOLANA

Um outro personagem que também vive em função de seu firmamento, enquanto cidadão angolano, é Teoria. Teoria é o professor da base e leva consigo o estigma de ser híbrido, tendo como objetivo "mostrar a um e a outros que há sempre um lugar para o talvez" (M, p. 12).

Como observa Costa, ${ }^{24}$

Sobredeterminado a partir do exterior pela marca indelével de sua cor café-com- leite, resultado da mistura de sua porção negra e branca, Teoria não tem vez nem no mundo dos brancos, nem no mundo dos negros, pela falta de reconhecimento de seu eu. Humanizado no drama de ser dois que é o de ser ninguém, ele tem de driblar o cerco que lhe é imposto pelo universo maniqueísta para conseguir SER.

Enquanto Sem Medo é o guerrilheiro que representa honestidade e entrega total a fim de libertar-se, Teoria é o guerrilheiro da simplicidade, da indecisão, o que não significa que ele seja covarde, muito pelo contrário Teoria procura sempre dar o melhor de si, mesmo porque, segundo ele: "Ofereço-me sempre para as missões, mesmo contra a opinião do comando: poderia recusar? Imediatamente se lembrariam de que não sou igual aos outros" (M, p. 17).

Na tentativa de arranjar um lugar para o híbrido, Teoria deixou para traz toda sua vida para lutar por uma sociedade que desse lugar ao diverso, pois, num país na situação em que Angola se encontrava, era possível defender a "pureza" de raças:

Trago em mim o inconciliável e é este o meu motor. Num universo de sim ou não, branco ou negro, eu represento o talvez. Talvez é não para quem quer ouvir sim e significa sim para quem quer ouvir não. A culpa será minha se os homens exigem a pureza e recusam as combinações? Sou eu que devo tornar-me em sim ou em não? Ou são os outros que devem aceitar o talvez ? (M, p.7).

24 Idem, p. 219 
E ainda: "Estou no Mayombe, renunciando a Manuela, com o fim de arranjar no universo maniqueísta o lugar para o talvez." (M, p.12).

Como dissemos anteriormente, cada guerrilheiro era impulsionado por verdades individuais, cada um possuía um segredo que o fazia combater:

Teoria sentia que o Comandante também tinha um segredo. Como cada um dos outros. E era esse segredo de cada um que os fazia combater, freqüentemente por razões longínquas das afirmadas. Por que Sem Medo abandonara o curso de economia, em 1964, para entrar na guerrilha? Por que o Comissário abandonara Caxito, o pai velho e pobre camponês arruinado pelo roubo das terras de café, e viera?[...] Por que o Chefe de Operações abandonara os Dembos? Por que Milagre abandonara a família? Por que Muatiânvua, o desenraizado, o marinheiro, abandonara os barcos para agora marchar a pé, numa vida de aventuras tão diferente da sua ? E por que ele Teoria, abandonara a mulher e a posição que podia facilmente adquirir? (M, p.11).

Teoria, ao contrário de Lutamos, que objetiva mostrar aos tribalistas que o povo de Cabinda não é de todo composta por traidores, tende fixar sua identidade como ser angolano. Teoria necessitava mostrar que, apesar de sua origem mestiça, é sobretudo angolano. Ele é o resultado do colonialismo e da dominação estrangeira. Diferente dos demais, ele tinha em comum com estes a luta contra o tribalismo.

A sociedade angolana, no período correspondente à narrativa, estava marcada economicamente por dois setores. O setor capitalista, que se encontrava moldado na lógica imperialista, e o setor tradicional, que era formado por nativos ligados à agricultura.O nativo produzia, geralmente, para o próprio consumo. Cabe salientar que o tribalismo era "cultivado" justamente neste setor tradicional da economia.

A competitividade tribal é algo tão forte que, apesar dos motivos aglutinadores que unem os guerrilheiros em torno de um só objetivo, consegue dividi-los internamente: 
Sem Medo escutava, mas estava também atento aos comentários do resto dos guerrilheiros. Estes dividiam-se em grosso modo em dois grupos: os kimbundos, os kinkkongos, umbundos e destribalizados como 0 Muatiânvua filho de pai umbundo e mãe kimbundo, nascido na Lunda. Mundo Novo era de Luanda, de orígem kimbundo, mas o estudo ou talvez a permanência na Europa tinham-no libertado do tribalismo (M, p. 35).

A tomada de posição assumida e destacada pelo grupo de guerrilheiros, na citação acima, acontece também em nível ideológico quando nos referimos às personagens Sem Medo, Comissário Político e Chefe de Operações. O comissário Político era o tipo de guerrilheiro que, ao contrário de Sem Medo, associava ao sacrifício da luta um futuro e bem estar individual. Já o Chefe de Operações está sempre indo de encontro às idéias defendidas pelo comissário. Nessa conversa entre Sem Medo e o Comissário Político, é possível perceber a divergência de idéias entre os superiores do comando:

- Somos três no comando, camarada. Se vocês dois não estiverem de acordo, eu inclino-me. Não sou ditador, bem sabes. (Sem Medo)

- Somos três? Vocês são dois!

Sem Medo fixou-o. Uma ruga cavou-se-lhe entre os olhos.

- Que queres dizer?

- Simplesmente que, desde que tu e eu não estejamos de acordo, vocês são dois e eu um. O Das operações vai sempre pelo teu lado. Até parece que nunca reparastes! (M, p.15).

No entanto, entre os personagens-guerrilheiros, Muatiânvua é o que tem um melhor posicionamento diante da realidade dos fatos. Por ter sido marinheiro, Muatiânvua conhece vários outros mundos e, consequientemente, várias outras realidades, o que lhe concede um posicionamento privilegiado em relação aos demais guerrilheiros. Muatiânvua é, como já dissemos, um destribalizado, e como tal, não compreende a lógica do tribalismo e do regionalismo naquela realidade em que vive: 
O mar foi por mim percorrido durante anos, de norte para sul, até à Namímbia, onde o deserto vem misturarse com a areia da praia, até ao Gabão e ao Chana, e ao Senegal, onde o verde das praias vai amarelecendo, até de novo se confundir com elas na Mauritânia, juntando a África do Norte à África Austral, no amarelo de suas praias. Marinheiro do Atlântico, e mesmo do Índico eu fui. Cheguei até mesmo à Arábia, e de novo encontrei as praias amarelas de Moçamedes e Benguela, onde cresci. Praias de Benguela, onde cresci. Praias de Benguela, praias da Mauritânia, praias da Arábia, não são as amarelas praias de todo Mundo ?[...]Querem que hoje eu seja tribalista 1

De que tribo?, pergunto. De que tribo, se eu sou de todas as tribos, não só de Angola, como de África? Não falo eu o Swahili, não aprendi eu o haussa com um nigeriano? Qual é a minha língua, eu, que não dizia uma frase sem empregar palavras de línguas diferentes? E agora que utilizo para falar com os camaradas, para deles ser compreendido? O Português. A que tribo angolana pertence a língua portuguesa? (M, p.133).

Emblemática da complexidade que envolve os conceitos centrais levantados na leitura de Mayombe: nação, identidade e utopia, as indagações colocadas, no início deste capítulo, corroboram com nossa abordagem, dado que na obra analisada temos vários personagens narradores que vivenciam a realidade angolana no período das guerras de libertação. Esses personagens nos indagam sobre os fatos narrados, na qualidade de confidentes, como uma atitude de desabafo, deixando espaço para que tomemos determinado posicionamento diante do que foi colocado.

Fica claro, na obra analisada, o desejo de construção de uma identidade nacional, que abarque a diversidade étnica e cultural angolana. Para isso, Pepetela sempre procurou, através de sua ficção, mostrar os conflitos tribais, regionais e sobretudo o drama de personagens crioulos, como é o caso de Teoria, ao optar por uma identidade mista. No entanto, devemos salientar que em nenhum lugar Pepetela toma partido com relação às tomadas decisões dos seus personagens, pois ele prima pela construção de uma identidade 
moldada nos ideais do MPLA, que objetiva a construção de uma identidade pluri-étnica, que tenha como elemento predominante a angolanidade.

Pepetela, através da utopia de construir uma identidade nacional angolana, marca, com seu repúdio e crítica, um distanciamento do existente, ao mesmo tempo em que marca uma alternativa mesmo que distante de realização, no sentido de superar seus males e carências.

No presente nunca haverá lugar para a utopia, pois não devemos esquecer que o termo significa "o não lugar". Não devemos esquecer, entretanto, que a utopia não é, mas deverá ser, ainda mais quando se trata da construção de uma identidade nacional

\section{Referências}

ANDRADE, Fenando Costa. Literatura angolana (Opiniões). Lisboa: Edições 70, 1971.

BACCEGA, Maria Aparecida. Mayombe: fiç̧ão e história (uma leitura em movimento) Tese de Doutorado. $\mathrm{O}$ autor: mimeo. Departamento de Letras Clássicas e Vernáculas da Faculdade de Filosofia, Letras e Ciências Humanas da Universidade de São Paulo, 1985.

CANDIDO, Antônio. O discurso e a idade. São Paulo: Duas Cidades, 1993.

CANDIDO, Mariana Pinho. Pepetela: um olhar sobre a construção da cultura nacional. Monografia de Bacharelado. O autor: mimeo. Instituto de Filosofia e Ciências Sociais - Departamento de História.Universidade Federal do Rio de Janeiro Rio de Janeiro, 1997.

CARVALHO FILHO, Silvio de Almeida. Imaginário sobre nação na literatura angolana(1975-1985). Atas do I Seminário das Literaturas Africanas de Lingua Portuguesa. Faculdade de Letras/UFRJ,1996. p. $16-18$. 
CHAVES, Rita. Pepetela: romance e utopia na história de Angola. Via atlântica. Departamento de Letras Clássicas e Vernáculas. Faculdade de Filosofia, Letras e Ciências humanas. Universidade de São Paulo. n 2 julho de 1999. São Paulo: Departamento: 1999, p.217232.

CHAVES, Rita. O passado presente na literatura angolana. Escript., Belo Horizonte, v.3, n.6, p.245-257, $1^{\circ}$ sem. 2000.

COSTA, Maria Gabriela. O Concerto das Vozes em Mayombe, de Pepetela. Littera; revista de estudos lingiiísticos e literários. São Luís: Departamento de Letras da Universidade Federal do Maranhão, 2002, p.215-225.

DUTRA, Ênio Morais. A literatura angolana de ênfase social: Y Exemplo de Mayombe. In Letras Hoje: Porto Alegre, v.26, n.1, março de 1991 .

GARCIA, Flávio. Pepetela: o escritor guerrilheiro de Mayombe. Atas do I Seminário das literaturas africanas de língua portuguesa. Faculdade de Letras da UERJ, 1996, p.57-60.

LAJOLO, Marisa. Do mundo da leitura para leitura do mundo. São Paulo: Ática, 2002.

LARANJEIRA, Pires. As literaturas africanas de língua portuguesa Identidade e Autonomia. In Escript., Belo Horizonte, v.3, n.6, p.237$244,1^{\circ}$ sem. 2000.

LEITE, Lígia Chiappini Morais. O foco narrativo. 6 ed. São Paulo: Àtica, 1993. Série Princípios.

MANHEIM, Karl. A Mentalidade Utópica. In Ideologia e Utopia. Rio de Janeiro: Zahar Editores, 1968.

MOURALES, Bernard. As contra literaturas. Coimbra: Livraria Almeida, 1982.Trad. António Filipe Rodrigues Marques e João David Pinto Correia. Posfácio de João David Pinto Correia.

MÜNSTER, Arno. Ernst Bloch: Filosofia da praxis e utopia concreta. São Paulo: Unesp, 1993.

ORTIZ, Renato. Um outro território. Ensaios sobre a mundialização. São Paulo: Olho D’agua, 1996.

PEPETELA. Mayombe. São Paulo: Ática, 1982. 
IDENTIDADE NACIONAL ANGOLANA

SAID, Edward. Cultura e imperialismo. Trad. Denise Botmann. $1^{\mathrm{a}}$ Reimpressão. Cia das letras.

TRIGO, Salvato. Introdução à literatura de expressão portuguesa. Volume 1, Porto: Brasília Editora, 1997.

VENÂNCIO, José Carlos. Literatura e poder na África Lusófona.. Lisboa: Ministério da Educação. Innstituto de Língua Portuguesa, 1992. VÁZQUEZ, Adolfo Sánchez. Entre a realidade e a utopia. Ensaios sobre política, moral e Socialismo. Trad. Gilson B. Soares. Rio de Janeiro: Civilização Brasileira, 2001.

www.estado.com.br/editoriais/2000/06/11/cad868.html. 